\title{
Molecular Identification of Mudskipper Fish (Periophthalmus spp.) from Baros Beach, Bantul, Yogyakarta
}

\author{
Katon Waskito Aji ${ }^{1}$, Tuty Arisuryanti ${ }^{1 *}$ \\ 1)Laboratory of Genetics and Breeding, Faculty of Biology, Universitas Gadjah Mada, Jl. Teknika Selatan, Sekip Utara, Yogyakarta \\ 55281 \\ * Corresponding author, email: tuty-arisuryanti@ugm.ac.id
}

Submitted: 07 June 2021; Accepted: 15 August 2021; Published online: 13 October 2021

\begin{abstract}
Mudskipper fish is amphibious fish belonging to the family Gobiidae. Coastal communities widely consume mudskipper to meet their animal protein needs. Mudskipper is primarily cryptic species that are morphologically difficult to identify and distinguish from other mudskipper fish species. Consequently, it can be confused with the naming of mudskipper fish species and can affect the conservation efforts of the fish in their habitat. One of the molecular approaches that can be used to identify the fish species quickly and accurately is DNA barcoding using the COI mitochondrial gene. However, the research on the identification of mudskipper fish in Indonesia is still very limited. Therefore, this study aimed to identify 26 mudskipper fish from Baros Beach, Bantul, Yogyakarta, using $C O I$ mitochondrial gene as a molecular marker for DNA barcoding. The method used in this study was a PCR method with universal primers, FishF2 and FishR2. The data obtained were then analyzed using GeneStudio, DNASTAR, BLAST, Identification Engine, Mesquite, MEGAX, and BEAST. The analysis was conducted to obtain similarity, genetic distance and reconstruct a phylogenetic tree. The result revealed that all 26 samples of mudskippers collected from Baros Beach were identified in one genus, namely Periophthalmus, and consisted of 3 species, namely $P$. kalolo (16 samples), $P$. argentilineatus (9 samples), and $P$. novemradiatus (1 sample). Furthermore, this study also discovered a suspected cryptic species in $P$. argentilineatus with a genetic distance of 5.46-5.96\% between clade E, F compared with clade G. Further morphological studies are needed to confirm the species status of these three clades before solidly proclaim that they are cryptic species.
\end{abstract}

Keywords: COI, cryptic species, DNA barcoding, mudskipper

\section{INTRODUCTION}

Mudskippers fish are classified into order Gobiiformes, family Gobiidae, and subfamily Oxudercinae (Murdy 1989; Van der Laan et al. 2014). The Gobiidae family comprises 258 genera and 1,850 fish species distributed in tropical and sub-tropical areas. One of the genera is Periophthlamus which consists of 19 valid species (Froese \& Pauly 2019). According to Pormansyah et al. (2019), 11 valid species of Periophthalmus have been recorded and spread over 7 major islands in Indonesia, namely Sumatera, Kalimantan, Java, Sulawesi, Moluccas, Lesser Sunda, and Papua. 
The mudskippers have few characteristics similar to those amphibious animals so that they are commonly recognized as amphibian fish. However, mudskipper's amphibious lifestyle is assisted by morphological and physiological adaptations such as aerial vision and olfaction, increased ammonia tolerance, terrestrial locomotion via pectoral fins, and enhanced immunological protection against pathogens (You et al. 2014; You et al. 2018). Coastal communities widely consume mudskippers because the fish contain high-quality sources of protein, minerals, and some vitamins (Andem \& Ekpo 2014; Kanejiya et al. 2017; Mahadevan et al. 2021).

Cryptic species are commonly found in the family Gobiidae (Thacker 2003). Previous studies showed that cryptic species has occurred in genus Elacatinus, Tigrigobius, Trimma, Eviota using COI mitochondrial gene (Victor 2010; Victor 2014; Winterbottom et al. 2014; Tornabene et al. 2015), genus Ponticola using Cyt-b mitochondrial gene (Vasil'eva et al. 2016) and genus Mugilogobius using three mitochondrial markers (ND5, Cytb, and D-loop) (Huang et al. 2016). Moreover, cryptic species are also observed in mudskippers Boleophthalmus pectinirostris from the western Pacific coast of East Asia and the Strait of Malacca in Malaysia using Mitochondrial ND5 gene and nuclear RAG-1 gene (Chen et al. 2014), Periopbthalmus argentilineatus from East-African and Indo-Malaya using two mtDNA markers (D-loop and 165 rDNA) and one nDNA region (RAG-1) (Polgar et al. 2014), and Periophthalmus argentilineatus from Bogowonto Lagoon, Yogyakarta, Indonesia using COI mitochondrial gene as a DNA barcoding marker (Arisuryanti et al. 2018). Since cryptic species are morphologically similar, distinguishing them solely on morphological characteristics is nearly impossible. Furthermore, the inaccurate identification of cryptic species can lead to taxonomic and conservation problems. In the last few years, molecular biology approaches have been applied for identifying fish species due to the limits of morphological identification methods. The most widely used method is DNA barcoding using the COI gene as a DNA barcoding marker (Hogg \& Hebert 2004). DNA barcoding is a method for quickly identifying species by examining a short specific target gene. This method can identify hidden species that previously cannot be identified by the conventional identification method (Hebert et al. 2003). Sequences from the mitochondrial COI gene are now considered highly desirable for the precise identification of freshwater fish species (Dahruddin et al. 2017; Hutama et al. 2017; Arisuryanti et al. 2020). This is because accurate species database information can be used to develop conservation programs for cryptic species.

Baros Beach has natural barriers such as land and different newly planted mangrove area that separate sub-populations of mudskipper fish. Moreover, there is no genetic information on mudskipper fish in this area. Therefore, this study aimed to identify mudskippers from Baros Beach Yogyakarta, Indonesia, using the COI mitochondrial gene as a DNA barcoding marker.

\section{MATERIALS AND METHODS}

\section{Sample collection}

A total of 26 mudskippers (code MBR) were collected from 4 different stations (A, B, C, and D) in Baros Beach (Figure 1) during August 2019 and December 2020. These stations were chosen by purposive sampling to represent the natural barriers in Baros Beach (Table 1). The sampling of mudskipper fish was performed using a hand net. Then, the sample was cleaned and documented (Figure 2). Each mudskipper fish sample was then placed in a plastic clip, placed in a cooler (coolbox), and transported to the Laboratory of Genetics and Breeding (Faculty of Biology, Universitas Gadjah 


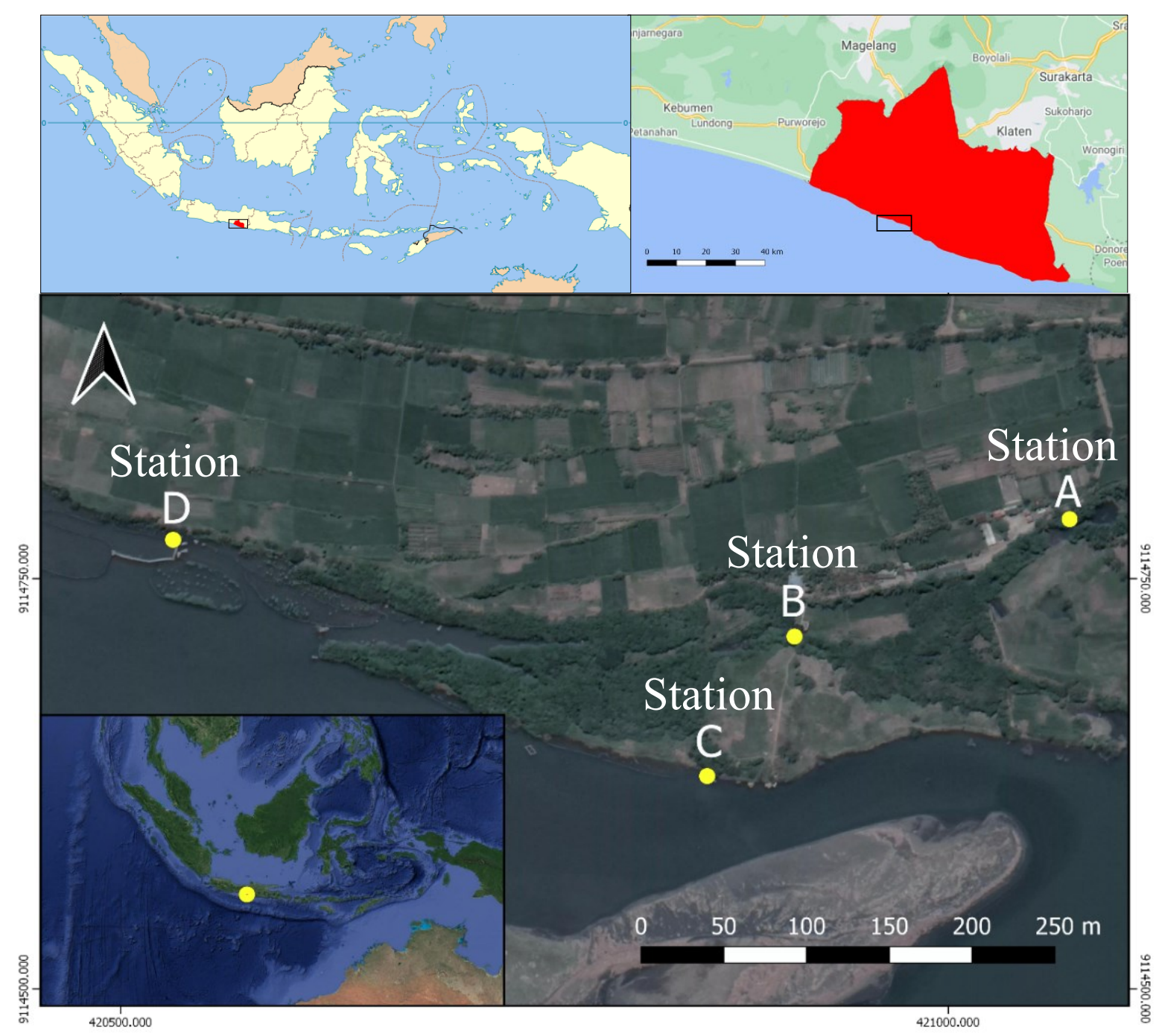

Figure 1. Map of sampling location for collecting mudskippers at Baros Beach, Bantul Yogyakarta, Indonesia.

Table 1. Coordinates and description of the sampling station.

\begin{tabular}{ccc}
\hline Station name & \multicolumn{1}{c}{ Coordinates } & \multicolumn{1}{c}{ Description } \\
\hline Station A & $8^{\circ} 00^{\prime} 27.4^{\prime \prime} \mathrm{S} 110^{\circ} 17^{\prime} 02.2^{\prime \prime} \mathrm{E}$ & Brackish muddy pond surrounded by mangrove trees \\
Station B & $8^{\circ} 00^{\prime} 29.9^{\prime \prime} \mathrm{S} 110^{\circ} 16^{\prime} 56.2^{\prime \prime} \mathrm{E}$ & Brackish muddy pond surrounded by mangrove trees \\
Station C & $8^{\circ} 00^{\prime} 32.7^{\prime \prime} \mathrm{S} 110^{\circ} 16^{\prime} 54.6^{\prime \prime} \mathrm{E}$ & Baros Beach Lagoon with a newly planted mangrove area \\
Station D & $8^{\circ} 00^{\prime} 27.9^{\prime \prime} \mathrm{S} 110^{\circ} 16^{\prime} 44.2^{\prime \prime} \mathrm{E}$ & A newly planted mangrove area \\
\hline
\end{tabular}

Mada) to be preserved with $99 \%$ ethanol and stored at $-20^{\circ} \mathrm{C}$ until used in the following process.

\section{DNA extraction}

The genomic DNA of each specimen was extracted from tissue muscle on the back of the gills above the pectoral fins using DNeasy blood and tissue kit (QIAGEN, Valencia, CA, USA), according to the manufacturer's protocols.

\section{DNA Amplification}

The partial COI mitochondrial gene was amplified using primers FishF2 (5'TCGACTAATCATAAAGATATCGGCAC-3') and FishR2 (5'-ACTTCAG GGTGACC GAAGAATCAGAA-3') (Ward et al. 2005) with T100 Thermal- 


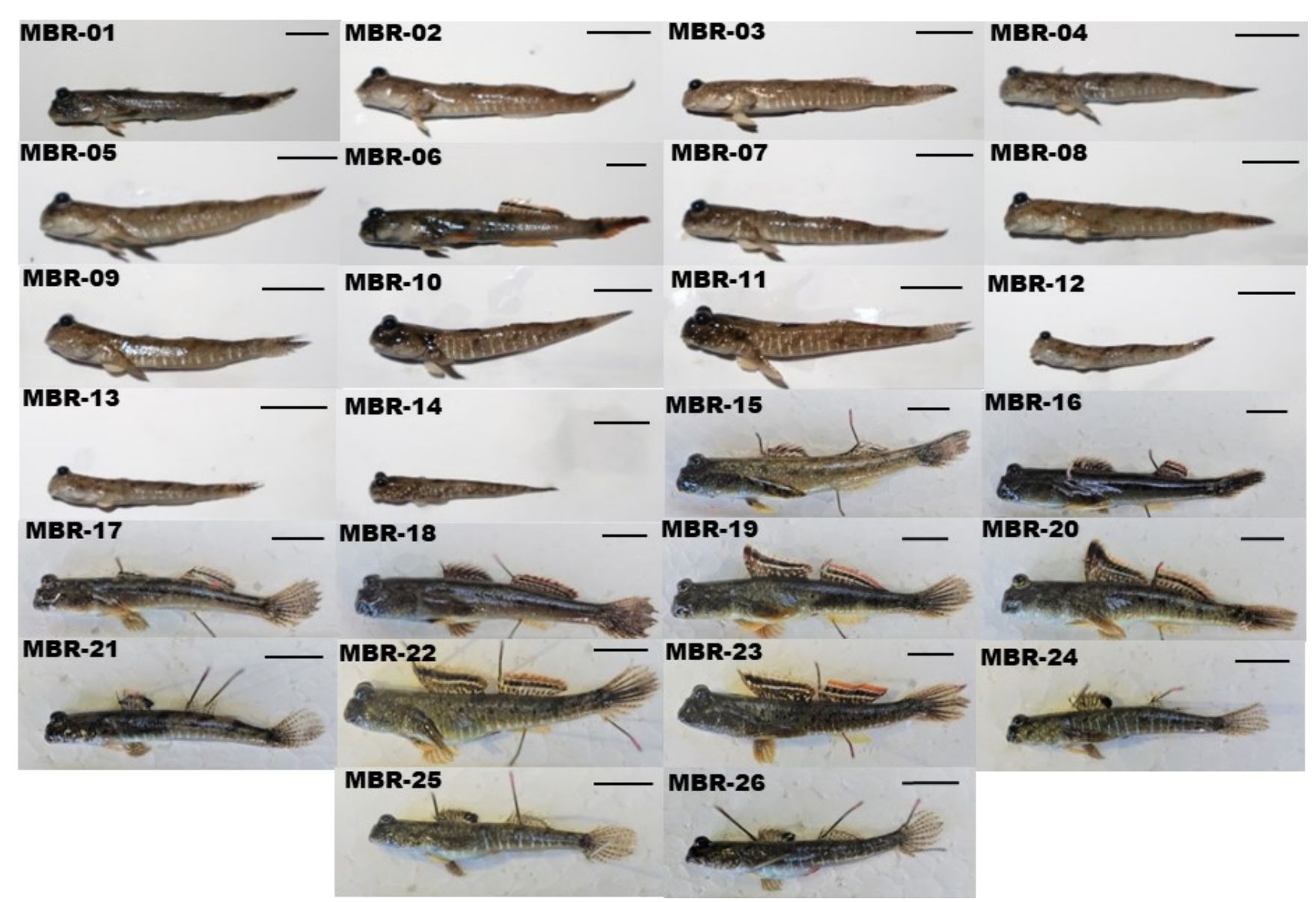

Figure 2. Mudskipper fish collected from Baros Beach. Bar $=1 \mathrm{~cm}$.

Cycler (Biorad). The MyTaq HS Red Mix PCR kit (Bioline) was used for the polymerase chain reaction (PCR), and PCR amplifications were performed in $50 \mu \mathrm{L}$ reaction volumes containing 10-100 ng of genomic DNA, $25 \mu \mathrm{L}$ MyTaq HS Red Mix PCR, $1 \mathrm{mM} \mathrm{MgCl}, 0.6 \mu \mathrm{M}$ of each primer and $11 \mu \mathrm{L}$ double distilled water (ddH2O). Negative control was set up by omitting template DNA from the reaction mixture to assess the efficiency of the DNA amplification. PCR amplification conditions were $2 \mathrm{~min}$ predenaturation at $95^{\circ} \mathrm{C}$, followed by 35 cycles of denaturation at $95^{\circ} \mathrm{C}$ for $15 \mathrm{sec}$, annealing at $50^{\circ} \mathrm{C}$ for $30 \mathrm{sec}$, and extension at $72^{\circ} \mathrm{C}$ for $30 \mathrm{sec}$. A final extension of $5 \mathrm{~min}$ at $72^{\circ} \mathrm{C}$ was performed (Arisuryanti et al. 2020).

Electrophoresis and Sequencing

The electrophoresis of PCR products was run on a 1\% agarose gel stained with Florosafe (Bioline) and buffered with Tris-acetate EDTA (TAE) at 50 volts for 20 minutes. Visualization was conducted under U.V. light. All amplification samples were sent to First Base Sdn Bhd (Malaysia) through P.T. Genetika Science (Jakarta) for purification and sequencing in both forward and reverse directions using the Big Dye Terminator (Applied Biosystems) and the ABI 3730xl Genetic Analyzer (Applied Biosystems).

\section{Sequence Editing}

Data obtained from DNA sequencing results were edited in the GeneStudio program and validated with SeqMan and EditSeq on the DNASTAR program (DNASTAR Inc. Madison, USA). Sequencing reactions were carried out on each individual using both forward and reverse primers. Chromatograms were inspected manually to check ambiguous bases and stop codons. 
Sequence Alignment

The mudskipper COI sequences were then aligned using Opal on Mesquite v.3.51 program (Maddison \& Maddison 2018) and ClustalW on the MEGAX program (Kumar et al. 2018).

\section{Nucleotide Composition \& Genetic Distance}

The composition of the COI nucleotides was calculated using the MEGAX program. Genetic distance was analyzed using the MEGAX program with the Kimura-2 Parameter (K2P) model and summarized in a NeighborJoining $(\mathrm{NJ})$ tree, which is the standard methodology used in barcoding studies with bootstrap 1,000 replicates (Hebert et al. 2003).

\section{Phylogenetic Relationship}

The reconstruction of the phylogeny tree was analyzed using the Neighbor Joining and Maximum Likelihood methods with 1,000 bootstrap using the MEGAX program (Kumar et al. 2018) and Bayesian Inference using the BEAST program (Suchard et al. 2018). The Bayesian Information Criterion (BIC) implemented in jModelTest 2.1.10 (Darriba et al. 2012) was used to determine the best fit evolutionary model. This study's most optimal sequence substitution model is $\mathrm{HKY}$ with invariant sites $(\mathrm{HKY}+\mathrm{I})$ on the Bayesian Information Criterion (BIC). The Markov Chain Monte Carlo (MCMC) was run for $10^{6}$ generations to estimate the posterior probabilities distribution with a sampling frequency set to every 1,000 generations. The consensus trees were visualized in FigTree 1.4.4 (Rambaut 2019).

\section{RESULTS AND DISCUSSION}

\section{PCR amplification \& sequence identification of mudskipper from} Baros Beach

The result showed that the amplification of the COI mitochondrial gene of 26 mudskipper fish from Baros Beach produced fragment length around 700 bp (Figure 3). The consensus sequence results from the chromatogram editing process were between 666-708 bp, which can be translated into 222236 amino acids. According to the results (Table 2), all 26 mudskippers collected from Baros Beach were identified in one genus, namely Periophthalmus, and consisted of three species: P. Kalolo (16 samples), $P$. argentilineatus (9 samples), and $P$. novemradiatus (1 sample). The similarity of the samples compared to the data in GenBank was $99.39-100 \%$ for P. kalolo, $97.70-100 \%$ for $P$. argentilineatus, and $100 \%$ for P. novemradiatus. All of the mudskipper samples collected and investigated from Baros Beach have been registered in GenBank with accession number MZ606679-MZ606687 for $P$. argentilineatus, accession number MZ614840-MZ614855 for $P$. kalolo, and accession number MZ614856 for $P$. novemradiatus.

\section{Sequence Alignment}

The alignment of sixteen $P$. kalolo sequence samples from Baros Beach yielded a clean sequence (a sequence that resulted after the alignment and cutting process) of $684 \mathrm{bp}$, meanwhile in nine $P$. argentilineatus sequence samples from Baros Beach resulted in a clean sequence of $648 \mathrm{bp}$. These clean $C O I$ gene sequences of each species were then used for intrapopulation analysis.

The COI sequences alignment of mudskippers from Baros Beach and other Indonesian regions recorded in GenBank and BOLD resulted in a fragment length of $579 \mathrm{bp}$ for $P$. kalolo and $P$. argentilineatus, $651 \mathrm{bp}$ for $P$. novemradiatus, respectively. This result was then subjected to intraspecies analysis (nucleotide composition and genetic distance). For phylogenetic tree 


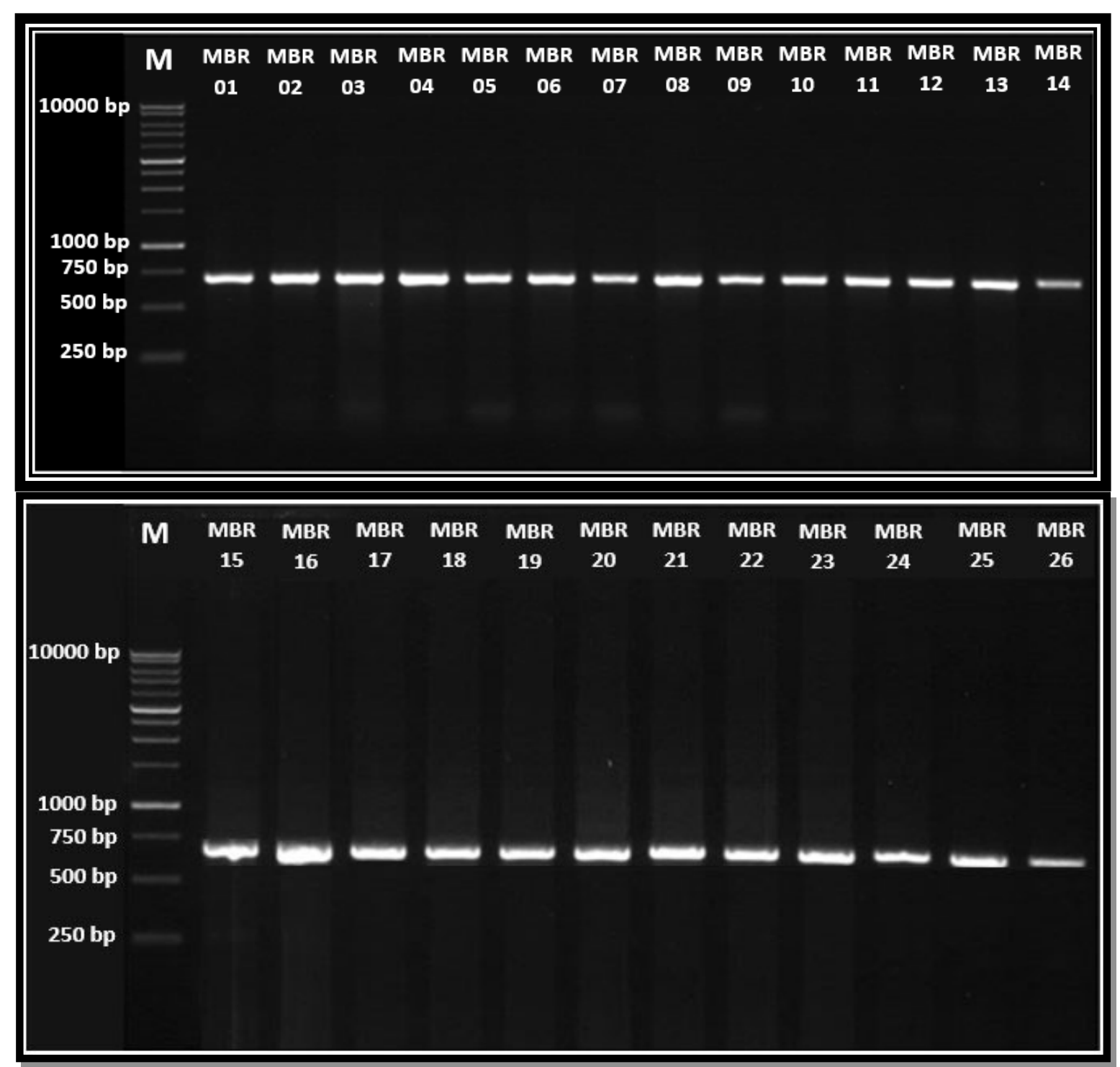

Figure 3. PCR amplification result of COI mitochondrial gene of mudskipper fish from Baros Beach migrated in $1 \%$ agarose electrophoresis. MBR 01 to 26 is the sample code. M is marker visualized from DNA ladder $1 \mathrm{~kb}$ (GENEAID).

analysis, the clean COI sequences (570 bp) of 44 samples representing 3 species, namely, P. kalolo, P. argentilineatus, and P. novemradiatus from Baros Beach and other Indonesian regions recorded on GenBank and BOLD were used. One COI sequence of Boleophthalmus boddarti (accession number KU692377) was used as an outgroup.

\section{Nucleotide Composition}

Intrapopulation

Both species ( $P$. kalolo and $P$. argentilineatus) had different nucleotide compositions of T, C, A, and G. In P. kalolo, the average nucleotide compositions of T, C, A, and G were 30.82\%, 26.75\%, 24.60\%, and $17.83 \%$, meanwhile in $P$. argentilineatus were $31.1 \% \%, 26.23 \%, 25.46 \%$, and $17.11 \%$ respectively. Both species had $\mathrm{A}+\mathrm{T}$ content higher than $\mathrm{G}+\mathrm{C}$, but the $\mathrm{G}+\mathrm{C}$ content was higher in $P$. kalolo $(44.58 \%)$ than in $P$. argentilineatus $(43.35 \%)$. The difference in T, C, A, and $G$ nucleotides between samples of P. kalolo were $0-1.02 \%, 0-1.17 \%, 0-0.43 \%$, and $0.15-0.59 \%$ respectively, meanwhile in $P$. argentilineatus, were $0-1.08 \%, 0.15-1.08 \% ; 0.16-0.47 \%$, and $0-0.30 \%$ respectively. Therefore, the nucleotide analysis indicated that there were variations in the intrapopulation of $P$. kalolo and $P$. argentilineatus from Baros Beach based on the COI mitochondrial gene. 
Table 2. Species identification based on GenBank database using BLAST and BOLD identification.

\begin{tabular}{|c|c|c|c|c|c|c|}
\hline No & $\begin{array}{l}\text { Sample } \\
\text { Code }\end{array}$ & $\begin{array}{l}\text { Identified Species from } \\
\text { GenBank/BOLD }\end{array}$ & $\begin{array}{l}\text { Similarity } \\
(\%)\end{array}$ & $\begin{array}{c}\text { Query } \\
\text { Cover } \\
(\%)\end{array}$ & $\begin{array}{l}\text { Accession } \\
\text { Number }\end{array}$ & References \\
\hline 1 & MBR-01 & Periophthalmus argentilineatus & 97.97 & 95 & $\begin{array}{l}\text { KU692745 } \\
\text { KU692746 }\end{array}$ & $\begin{array}{c}\text { Dahruddin et al. } \\
\text { (2017) }\end{array}$ \\
\hline 2 & MBR-02 & Periophthalmus kalolo & 99.85 & 92 & KU692750 & $\begin{array}{l}\text { Dahruddin et al. } \\
\text { (2017) }\end{array}$ \\
\hline 3 & MBR-03 & Periophthalmus kalolo & 99.54 & 92 & KU692750 & $\begin{array}{l}\text { Dahruddin et al. } \\
(2017)\end{array}$ \\
\hline 4 & MBR-04 & Periophthalmus kalolo & 99.85 & 92 & $\begin{array}{l}\text { KU692747 } \\
\text { KU692751 }\end{array}$ & $\begin{array}{l}\text { Dahruddin et al. } \\
\text { (2017) }\end{array}$ \\
\hline 5 & MBR-05 & Periophthalmus kalolo & 100 & 94 & KU692753 & $\begin{array}{l}\text { Dahruddin et al. } \\
(2017)\end{array}$ \\
\hline 6 & MBR-06 & Periophthalmus novemradiatus & 100 & 92 & $\begin{array}{l}\text { KU692756 } \\
\text { KU692759 } \\
\text { KU692760 } \\
\text { KU692763 } \\
\text { KU692764 }\end{array}$ & $\begin{array}{l}\text { Dahruddin et al. } \\
\text { (2017) }\end{array}$ \\
\hline 7 & MBR-07 & Periophthalmus kalolo & 99.85 & 92 & $\begin{array}{l}\text { KU692747 } \\
\text { KU692751 }\end{array}$ & $\begin{array}{l}\text { Dahruddin et al. } \\
\text { (2017) }\end{array}$ \\
\hline 8 & MBR-08 & Periophthalmus kalolo & 100 & 92 & KU692752 & $\begin{array}{l}\text { Dahruddin et al. } \\
\text { (2017) }\end{array}$ \\
\hline 9 & MBR-09 & Periophthalmus kalolo & 100 & 92 & KU692750 & $\begin{array}{l}\text { Dahruddin et al. } \\
\text { (2017) }\end{array}$ \\
\hline 10 & MBR-10 & Periophthalmus kalolo & 99.69 & 92 & $\begin{array}{l}\text { KU692753 } \\
\text { MT439601 } \\
\text { MT439602 }\end{array}$ & $\begin{array}{l}\text { Dahruddin et al. } \\
\qquad(2017) ; \\
\text { Arisuryanti et al. } \\
\qquad(2018)\end{array}$ \\
\hline 11 & MBR-11 & Periophthalmus kalolo & 99.85 & 92 & $\begin{array}{l}\text { KU692747 } \\
\text { KU692751 }\end{array}$ & $\begin{array}{l}\text { Dahruddin et al. } \\
\text { (2017) }\end{array}$ \\
\hline 12 & MBR-12 & Periophthalmus kalolo & 99.54 & 93 & $\begin{array}{l}\text { KU692747 } \\
\text { KU692751 } \\
\text { KU692752 }\end{array}$ & $\begin{array}{l}\text { Dahruddin et al. } \\
\text { (2017) }\end{array}$ \\
\hline 13 & MBR-13 & Periophthalmus kalolo & 99.69 & 94 & $\begin{array}{l}\text { KU692747 } \\
\text { KU692751 }\end{array}$ & $\begin{array}{l}\text { Dahruddin et al. } \\
\text { (2017) }\end{array}$ \\
\hline 14 & MBR-14 & Periophthalmus kealolo & 99.85 & 92 & KU692752 & $\begin{array}{c}\text { Dahruddin et al. } \\
\text { (2017) }\end{array}$ \\
\hline 15 & MBR-15 & Periophthalmus argentilineatus & 97.70 & 94 & $\begin{array}{l}\text { KU692745 } \\
\text { KU692746 }\end{array}$ & $\begin{array}{c}\text { Dahruddin et al. } \\
\text { (2017) }\end{array}$ \\
\hline 16 & MBR-16 & Periophthalmus argentilineatus & 97.85 & 92 & $\begin{array}{l}\text { KU692745 } \\
\text { KU692746 }\end{array}$ & $\begin{array}{c}\text { Dahruddin et al. } \\
\text { (2017) }\end{array}$ \\
\hline 17 & MBR-17 & Periophthalmus argentilineatus & 97.70 & 92 & $\begin{array}{l}\text { KU692745 } \\
\text { KU692746 }\end{array}$ & $\begin{array}{c}\text { Dahruddin et al. } \\
\text { (2017) }\end{array}$ \\
\hline 18 & MBR-18 & Periophthalmus argentilineatus & 97.78 & 95 & $\begin{array}{l}\text { KU692745 } \\
\text { KU692746 }\end{array}$ & $\begin{array}{l}\text { Dahruddin et al. } \\
\text { (2017) }\end{array}$ \\
\hline 19 & MBR-19 & Periophthalmus argentilineatus & 100 & 92 & $\begin{array}{l}\text { KU692745 } \\
\text { KU692746 }\end{array}$ & $\begin{array}{c}\text { Dahruddin et al. } \\
\text { (2017) }\end{array}$ \\
\hline 20 & MBR-20 & Periophthalmus argentilineatus & 99.69 & 92 & $\begin{array}{l}\text { KU692745 } \\
\text { KU692746 }\end{array}$ & $\begin{array}{c}\text { Dahruddin et al. } \\
\text { (2017) }\end{array}$ \\
\hline 21 & MBR-21 & Periophthalmus kalolo & 99.69 & $\begin{array}{l}92 \\
92 \\
92\end{array}$ & $\begin{array}{l}\text { KU692753 } \\
\text { MT439601 } \\
\text { MT439602 }\end{array}$ & $\begin{array}{l}\text { Dahruddin et al. } \\
\qquad(2017) \text {; } \\
\text { Arisuryanti et al. } \\
\text { (2018) }\end{array}$ \\
\hline 22 & MBR-22 & Periophthalmus argentilineatus & 100 & 94 & $\begin{array}{l}\text { KU692745 } \\
\text { KU692746 } \\
\end{array}$ & $\begin{array}{c}\text { Dahruddin et al. } \\
(2017)\end{array}$ \\
\hline
\end{tabular}


Table 2. Contd.

\begin{tabular}{|c|c|c|c|c|c|c|}
\hline No & $\begin{array}{l}\text { Sample } \\
\text { Code }\end{array}$ & $\begin{array}{l}\text { Identified Species from } \\
\text { GenBank/BOLD }\end{array}$ & $\begin{array}{l}\text { Similarity } \\
\qquad(\%)\end{array}$ & $\begin{array}{c}\text { Query } \\
\text { Cover } \\
(\%)\end{array}$ & $\begin{array}{l}\text { Accession } \\
\text { Number }\end{array}$ & References \\
\hline 23 & MBR-23 & Periophthalmus argentilineatus & 99.86 & 99 & MW514024 & $\begin{array}{l}\text { Rha'ifa et al. } \\
\text { (2021) }\end{array}$ \\
\hline 24 & MBR-24 & Periophthalmus kalolo & 99.39 & 92 & $\begin{array}{l}\text { KU692752 } \\
\text { KU692751 } \\
\text { KU692747 }\end{array}$ & $\begin{array}{l}\text { Dahruddin et al. } \\
\text { (2017) }\end{array}$ \\
\hline 25 & MBR-25 & Periophthalmus kalolo & 99.85 & 92 & $\begin{array}{l}\text { KU692751 } \\
\text { KU692747 }\end{array}$ & $\begin{array}{l}\text { Dahruddin et al. } \\
\text { (2017) }\end{array}$ \\
\hline 26 & MBR-26 & Periophthalmus kalolo & 99.85 & 92 & KU692750 & $\begin{array}{l}\text { Dahruddin et al. } \\
\text { (2017) }\end{array}$ \\
\hline
\end{tabular}

Intraspecies

The analysis showed that all $P$. kalolo samples had different T, C, A, and G nucleotide compositions. The differences of T, $\mathrm{C}, \mathrm{A}$, and $\mathrm{G}$ nucleotides between samples were $0-0.87 \%, 0-1.04 \%, 0-0.35 \%$, and $0-0.34 \%$, respectively. The composition of $\mathrm{A}+\mathrm{T}$ was greater than $\mathrm{G}+\mathrm{C}$. The GC content from all $P$. kalolo samples ranged from $43.18 \%$ to $44.21 \%$. The maximum GC content was observed in $P$. kalolo from Tulungagung (KU692748) and from Cilacap (KU692749). In addition, P. kalolo from Tulungagung (KU692747, KU692751, KU692755) had nucleotide compositions similar to one another. Furthermore, P. kalolo from Cilacap (KU692753) and Bogowonto (MT439602, MT439601) had the same nucleotide composition. This variation in nucleotide composition indicated variations between $P$. kalolo from the Baros Beach and $P$. kalolo from other Indonesian regions recorded in GenBank and BOLD based on the mitochondrial COI gene.

All $P$. argentilineatus samples had different T, C, A, and G nucleotide compositions. The differences of T, $\mathrm{C}, \mathrm{A}$, and $\mathrm{G}$ nucleotide between samples were $0.17-0.69 \%, 0-0.52 \%, 0-0.19 \%$, and $0.02-0.3 \%$, respectively. The composition of $\mathrm{A}+\mathrm{T}$ was greater than that of $\mathrm{G}+\mathrm{C}$. The $\mathrm{GC}$ content from all $P$. argentilineatus samples ranged from $42.14 \%$ to $42.66 \%$. The maximum GC content was observed in P. argentilineatus from Pandeglang (KU692744). Furthermore, $P$. argentilineatus from Pandeglang (KU692745-46) and P. argentilineatus from Bogowonto (MT439599) had the same nucleotide composition. This variation of nucleotide composition indicated that there were intraspecies variations of $P$. argentilineatus from Baros Beach and $P$. argentilineatus from other Indonesian regions recorded in GenBank and BOLD based on the mitochondrial COI gene.

$P$. novemradiatus Baros Beach and P. novemradiatus from other Indonesian regions recorded in GenBank and BOLD had relatively similar nucleotide compositions of T, C, A, and G. The differences in T, C, A, and G nucleotides between samples were $0-0.30 \%, 0.15-0.46 \%, 0-0.15 \%$, and $0 \%$, respectively. The composition of $\mathrm{A}+\mathrm{T}$ being greater than the composition of $\mathrm{G}+\mathrm{C}$. The GC content from all P. novemradiatus samples ranged from $46.24 \%$ to $46.70 \%$. This variation in nucleotide composition indicated variations of P. novemradiatus from Baros Beach and P. novemradiatus from other Indonesian regions recorded in GenBank and BOLD based on the mitochondrial COI gene.

Phylogenetic analysis

The tree reconstruction results yielded identical tree topologies (Figure 4). The results of the jModelTest 2 analysis revealed that the most optimal 


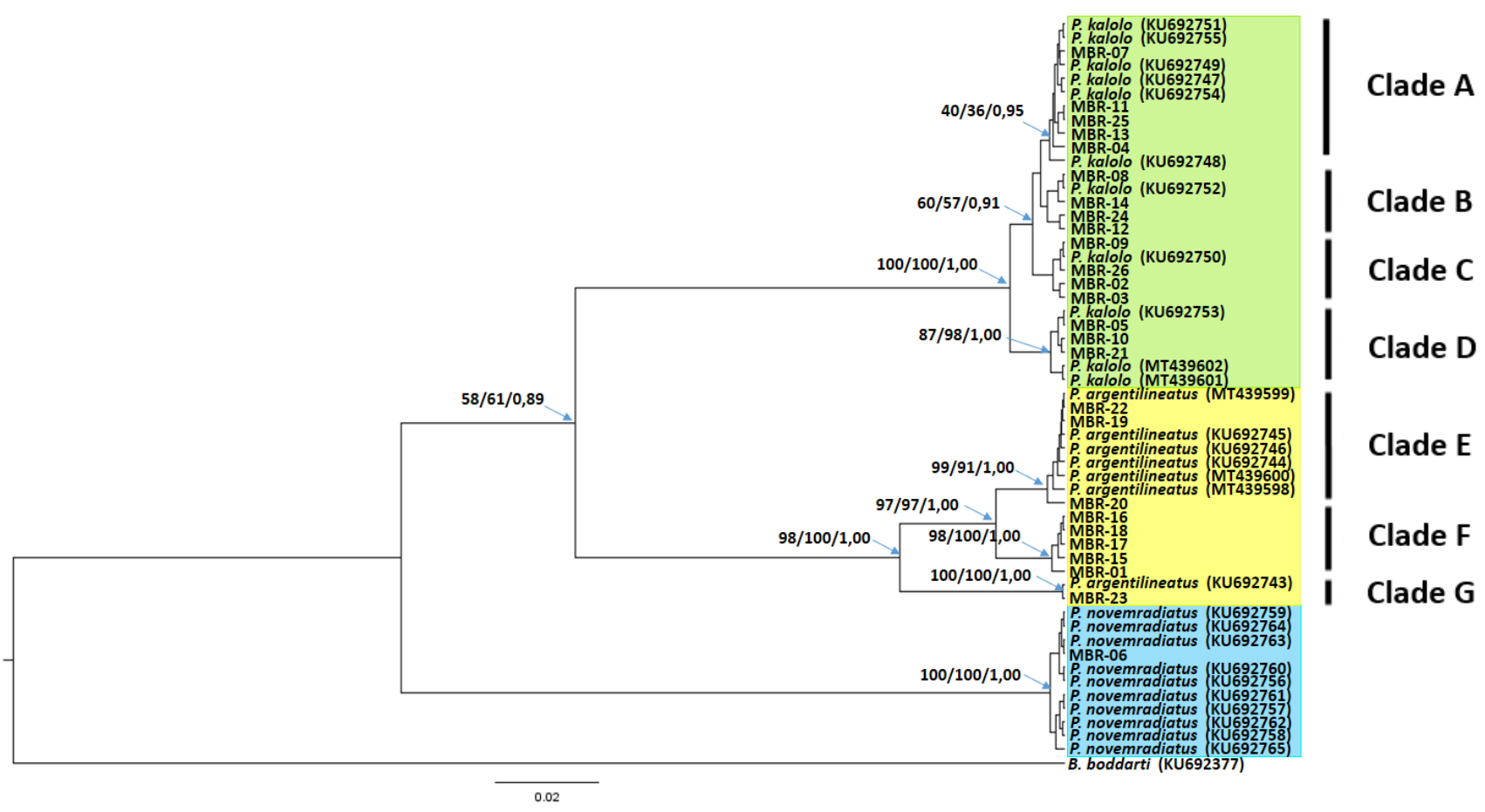

Figure 4. Phylogenetic tree reconstruction based on Neighbor-Joining (NJ), Maximum-Likelihood (ML), Bayesian Inference (BI) topology Periophthalmus spp. and outgroup based on COI gene sequences (570 bp). The node represented the number bootstrap (NJ and ML) and Bayesian Posterior Probability (Bayesian Inference).

sequence substitution model is $\mathrm{HKY}$ with invariant sites $(\mathrm{HKY}+\mathrm{I})$ on the Bayesian Information Criterion (BIC).

The phylogenetic tree reconstruction of $P$. kalolo from Baros Beach and P. kalolo from other regions in Indonesia recorded on GenBank and BOLD formed 4 different clades, namely Clade A, B, C, and D. The formation of these 4 clades were supported by a bootstrap value of $100 \%$ in the Neighbor-Joining and Maximum Likelihood methods. In addition, the posterior probability value is 1.00 in Bayesian Inference. Bootstrap and posterior probability results showed that the formation of these 4 clades was powerful and rigid. The results of the grouping above were consistent with previous studies conducted by Arisuryanti et al. (2018), which showed that P. kalolo from Bogowonto formed a group with P. kalolo from Cilacap (KU692753) and separated from P. kalolo from Tulungagung (KU692747-48, KU692750-52, KU692755) and other P. kalolo from Cilacap (KU692753 and KU692754).

The phylogenetic tree reconstruction of $P$. argentilineatus from Baros Beach and P. argentilineatus from regions in Indonesia recorded on GenBank and BOLD formed 3 different clades, consisting of clade $\mathrm{E}$, clade F, and clade $\mathrm{G}$. The formation of these 3 clades was supported by a bootstrap value of $98 \%$ in the Neighbor-Joining method, 100\% in Maximum Likelihood, and posterior probability value of 1.00 on Bayesian Inference. Bootstrap and posterior probability results showed that the formation of these 3 clades was powerful and rigid. The separation of clade $E$ and clade $F$ was supported by morphological data in which $P$. argentilineatus members of clade $\mathrm{E}$ had a pointed first dorsal fin shape, while members of clade $F$ had a rounded first dorsal fin shape.

The reconstruction of the phylogenetic tree of $P$. novemradiatus from Baros Beach with P. novemradiatus from other Indonesian regions recorded on GenBank and BOLD formed one clade of P. novemradiatus, which was supported by a bootstrap value of 100\% in the Neighbor-Joining and Maximum Likelihood methods, and a posterior probability of 1.00 on the Bayesian Inference. 


\section{Genetic Distance}

The lowest genetic distance was between $P$. kalolo clade $\mathrm{B}$ and $\mathrm{C}$ with an average of $0.66 \%(0.35-1.05 \%)$, while the highest genetic distance was between clade A and D with an average of 1.90\% (1.40-2.29\%) (Table 3). According to Zemlak et al. (2009), the threshold for intraspecies genetic distance in fish species is $3.5 \%$. If it exceeds $3.5 \%$, it is considered a different species. Based on the criterion from Zemlak above, P. kalolo from Baros Beach and $P$. kalolo from the Indonesian regions recorded in GenBank were still classified as the same species (conspecific).

The average genetic distance of $P$. argentilineatus between clade $\mathrm{E}$ and clade $\mathrm{F}$ was $2.51 \%$ (1.94-2.84\%), between clade $\mathrm{E}$ and clade $\mathrm{G}$ was $5.96 \%$ (5.62-6.19\%), and then between clade $\mathrm{F}$ and clade $\mathrm{G}$ was $5.46 \%(5.24-5.62 \%)$ (Table 4). Therefore, according to Zemlak's criterion, clade $\mathrm{E}$ and clade $\mathrm{F}$ were still classified as the same species (conspecific) because their genetic distance was less than $3.5 \%$, while clade $\mathrm{E}$ and clade $\mathrm{F}$ compared with clade $\mathrm{G}$ were suspected to be cryptic species because their genetic distance was more significant than $3.5 \%$. This finding was consistent with the study conducted by Arisuryanti et al. (2018) and Rha'ifa et al. (2021), who discovered that $P$. argentilineatus in Indonesia was divided into two clades separated by a genetic distance $>3,5 \%$. The results of the study further showed that $P$. argentilineatus in Indonesia are suspected to be cryptic species. Further studies are needed to examine whether P. argentilineatus in Indonesia should be categorized into different species or categorized into one species with several sub-species.

The average genetic distance of $P$. novemradiatus was $0.13 \%(0-0.30 \%)$. Based on the Zemlak criterion, P. novemradiatus from Baros Beach and $P$. novemradiatus from other Indonesian regions recorded in GenBank were still classified as the same species (conspecific).

Table 3. Percentage of an intra-species genetic distance of $P$. kalolo from Baros Beach and P. kalolo from other regions in Indonesia recorded in GenBank and BOLD based on the COI mitochondrial gene.

\begin{tabular}{|c|c|c|c|c|}
\hline & Clade A & Clade B & Clade C & Clade D \\
\hline Clade A & & & & \\
\hline Clade B & $\begin{array}{c}0.72 \\
(0.35-1.05)\end{array}$ & & & \\
\hline Clade C & $\begin{array}{c}0.98 \\
(0.52-1.40)\end{array}$ & $\begin{array}{c}0.66 \\
(0.35-1.05)\end{array}$ & & \\
\hline Clade D & $\begin{array}{c}1.90 \\
(1.40-2.29)\end{array}$ & $\begin{array}{c}1.62 \\
(1.22-1.93)\end{array}$ & $\begin{array}{c}1.39 \\
(1.05-1.75)\end{array}$ & \\
\hline
\end{tabular}

Table 4. Percentage of an intraspecies genetic distance of $P$. argentilineatus from Baros Beach and $P$. argentilineatus from other regions in Indonesia recorded in GenBank and BOLD based on the COI mitochondrial gene.

Clade E 


\section{CONCLUSION}

The identification of 26 mudskippers fish from Baros Beach revealed that they were identified in 1 genus, namely Periophthalmus, and consists of 3 species, namely P. kalolo (16 samples), P. argentilineatus (9 samples), and $P$. novemradiatus (1 sample). The similarity of the samples compared to the data in GenBank was $99.39-100 \%$ for P. kalolo, $97.70-100 \%$ for $P$. argentilineatus, and $100 \%$ for $P$. novemradiatus. The genetic relationship results showed that $P$. kalolo and $P$. novemradiatus from Baros Beach were still classified into their respective species. The phylogenetic tree showed that $P$. argentilineatus from Baros Beach consisted of 3 clades, consisting of clade $\mathrm{E}$, clade $\mathrm{F}$, and clade $\mathrm{G}$. The average genetic distance between clade $\mathrm{E}$ and clade $\mathrm{F}$ was $2.51 \%$, between clade $\mathrm{E}$ and clade $\mathrm{G}$ was $5.96 \%$, and between clade $\mathrm{F}$ and clade $\mathrm{G}$ was $5.46 \%$. That result revealed cryptic species on $P$. argentilineatus examined in this study. Further morphological studies are required to confirm the species status of these 3 clades before solidly proclaim that they are cryptic species.

\section{AUTHORS CONTRIBUTION}

T.A. planned, designed the research work, and supervised all the processes. KWA performed laboratory works (collecting samples, DNA extraction, PCR amplification, agarose gel electrophoresis, data analysis, and writing manuscript).

\section{ACKNOWLEDGMENTS}

We would like to thank the Head of the Laboratory of Genetics and Breeding for granting permission and facilitating this research. We also like to thank everyone who helped collect mudskipper fish samples from Baros Beach, Yogyakarta.

\section{CONFLICT OF INTEREST}

The authors state that they do not have any conflicts of interest. However, the authors are responsible for the article's content and writing.

\section{REFERENCES}

Andem, A.B. \& Ekpo, P.B., 2014. Proximate and mineral compositions of mudskipper fish (Periophthalmus barbarus) in the mangrove swamp of Calabar River, southern Nigeria. The International Journal of Science and Technoledge, 2(2), pp.72-76.

Arisuryanti, T. et al., 2018. Genetic identification of two mudskipper species (Pisces: Gobiidae) from Bogowonto Lagoon (Yogyakarta, Indonesia) using COI mitochondrial gene as a DNA barcoding marker. AIP Conference Proceedings, 2002, 020068.

Arisuryanti, T. et al., 2020. Genetic characterization of striped snakehead (Channa striata Bloch, 1793) from Arut River, Central Kalimantan inferred from COI mitochondrial gene. AIP Conference Proceedings, 2260, 020001.

Chen, H. et al., 2014. Cryptic species and evolutionary history of the Boleophthalmus pectinirostris complex, along the northwestern Pacific coast. Acta Hydrobiologica Sinica, 38(1), pp.75-86.

Dahruddin, H. et al., 2017. Revisiting the ichthyodiversity of Java and Bali through DNA barcodes: taxonomic coverage, identification accuracy, cryptic diversity and identification of exotic species. Molecular Ecology Resources, 17(2), pp.288-299.

Darriba, D. et al., 2012. jModelTest 2: more models, new heuristics and parallel computing. Nature methods, 9(8), pp.772-772. 
Froese, R. et al., 2019. FishBase. in W orld Wide Web electronic publication, viewed 28 May 2021, from http://www.fishbase.org, version (12/2019).

Hebert, P.D. et al., 2003. Barcoding animal life: cytochrome c oxidase subunit 1 divergences among closely related species. Proceedings of the Royal Society of London. Series B: Biological Sciences, 270(suppl_1), pp.S96S99.

Hogg, I.D. \& Hebert, P.D., 2004. Biological identification of springtails (Hexapoda: Collembola) from the Canadian Arctic, using mitochondrial DNA barcodes. Canadian Journal of Zoology, 82(5), pp.749754.

Huang, S. P. et al., 2016. The recognition and molecular phylogeny of Mugilogobius mertoni complex (Teleostei: Gobiidae), with description of a new cryptic species of $M$. flavomaculatus from Taiwan. Zoological Studies, 55 , e39.

Hutama, A. et al., 2017. Identifying spatially concordant evolutionary significant units across multiple species through DNA barcodes: Application to the conservation genetics of the freshwater fishes of Java and Bali. Global Ecology and Conservation, 12, pp.170-187.

Kanejiya, J. et al., 2017. Nutrient content of three species of Mudskipper (Gobiidae; Oxudercinae) in Bhavnagar coast, Gujarat, India. Liver, 2, pp.2-5.

Kumar, S. et al., 2018. MEGA X: Molecular evolutionary genetics analysis across computing platforms. Molecular Biology and Evolution 35, pp.15471549.

Maddison, W. P. \& Maddison, D. R., 2018. Mesquite: a modular system for evolutionary analysis. Evolution, 62, pp.1103-1118.

Mahadevan, G. et al., 2021. Nutritional evaluation of elongate mudskipper Pseudapocryptes elongatus (Cuvier, 1816) from Diamond Harbor, West Bengal, India. Natural Product Research, 35, pp.2715-2721.

Murdy, E.O., 1989. A taxonomic revision and cladistic analysis of the oxudercine gobies (Gobiidae: Oxudercinae). Records of the Australian Museum, Supplement, 11(August 1989), pp.1-93.

Polgar, G. et al., 2014. Phylogeography and demographic history of two widespread Indo-Pacific mudskippers (Gobiidae: Periophthalmus). Molecular Phylogenetics and Evolution, 73, pp.161-176.

Pormansyah et al., 2019. A review of recent status on Mudskippers (Oxudercine Gobies) in Indonesian Waters. Oceanography and Fisheries, 9 (4), 555769.

Rambaut, A. 2019, 'FigTree v 1.4.4.' viewed 31 March 2021, from http:/ / tree.bio.ed.ac.uk/software/figtree/.

Rha'ifa, F. A. et al., 2021. DNA barcode of barred mudskipper (Periophthalmus argentilineatus Valenciennes, 1837) from Tekolok Estuary (West Nusa Tenggara, Indonesia) and their phylogenetic relationship with other Indonesian barred mudskippers. Journal of Tropical Biodiversity and Biotechnology, 6(2), jtbb.59702.

Suchard, M.A. et al., 2018. Bayesian phylogenetic and phylodynamic data integration using BEAST 1.10. Virus evolution, 4(1), vey016.

Thacker, C.E., 2003. Molecular phylogeny of the gobioid fishes (Teleostei: Perciformes: Gobioidei). Molecular Phylogenetics and Evolution, 26(3), pp.354-368.

Tornabene, L. et al., 2015. Support for a 'Center of Origin'in the Coral Triangle: Cryptic diversity, recent speciation, and local endemism in a diverse lineage of reef fishes (Gobiidae: Eviota). Molecular Phylogenetics and Evolution, 82, pp.200-210.

Van Der Laan, R. et al., 2014. Family-group names of recent fishes. Zootaxa, 3882(1). 
Vasil'eva, E.D. et al., 2016. Cryptic species of Ponto-Caspian bighead goby of the genus Ponticola (Gobiidae). Journal of Ichtbyology, 56(1), pp.3-21.

Victor, B.C., 2010. The Redcheek Paradox: the mismatch between genetic and phenotypic divergence among deeply-divided mtDNA lineages in a coral-reef goby, with the description of two new cryptic species from the Caribbean Sea. Journal of the Ocean Science Foundation, 3(1), pp.1-16.

Victor, B.C., 2014. Three new endemic cryptic species revealed by DNA barcoding of the gobies of the Cayman Islands (Teleostei: Gobiidae). Journal of the Ocean Science Foundation, 12, pp.25-60.

Winterbottom, R. et al., 2014. A cornucopia of cryptic species-a DNA barcode analysis of the gobiid fish genus Trimma (Percomorpha, Gobiiformes). ZooKeys, 381, pp.79-111.

You, X. et al., 2014. Mudskipper genomes provide insights into the terrestrial adaptation of amphibious fishes. Nature Communications, 5(1), 5594.

You, X. et al., 2018. Mudskippers and their genetic adaptations to an amphibious lifestyle. Animals, 8(2), 24.

Zemlak, T.S. et al., 2009. DNA barcoding reveals overlooked marine fishes. Molecular Ecology Resources, 9, pp.237-242. 